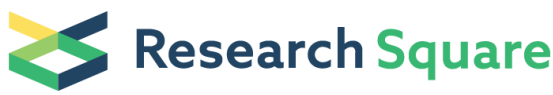 \\ Preprints are preliminary reports that have not undergone peer review. \\ They should not be considered conclusive, used to inform clinical practice, or referenced by the media as validated information.
}

\section{Wheat Quality Estimation Using Vision-Based Digital Image Analysis}

\author{
Edina Csákvári ( $\nabla$ csakvari.edina@ecolres.hu ) \\ Centre for Ecological Research https://orcid.org/0000-0002-1089-7603 \\ Melinda Halassy \\ Centre for Ecological Research \\ Attila Enyedi \\ Gábor Dénes Foiskola: Gabor Denes Foiskola \\ Ferenc Gyulai \\ Szent István University \\ József Berke \\ Gábor Dénes Foiskola: Gabor Denes Foiskola
}

\section{Research Article}

Keywords: RGB camera, digital image analysis, aboveground biomass, winter wheat, einkorn

Posted Date: March 11th, 2021

DOI: https://doi.org/10.21203/rs.3.rs-266773/v1

License: (c) (i) This work is licensed under a Creative Commons Attribution 4.0 International License. Read Full License

Version of Record: A version of this preprint was published at Sustainability on October 29th, 2021. See the published version at https://doi.org/10.3390/su132112005. 


\section{Abstract}

\section{Background}

Einkorn wheat (Triticum monococcum L. subs. monococcum) plays an increasingly important role in agriculture, promoted by organic farming. Although the number of comparative studies about modern and ancient types of wheats are increasing, there are still some knowledge gaps. The aim of the present study was to compare ancient, traditional and modern wheats using novel methods, including field study, laboratory stress experiment and vision-based digital image analysis. The yield and grain quality parameters based on the field experiment were measured with a near-infrared optical laboratory analyser. In order to predict the aboveground biomass production under nutrient deficiency and drought stress, a controlled experiment was set up in a growth chamber. Processing was performed by image segmentation using the Adobe Photoshop CC 20.04.4 Camera RAW 11.2 plug-in. Digital image parameters were determined with the open source software ImageJ and expressed in pixels of projected area, perimeter, bounding rectangle and Feret's diameter.

Results

We presented a fast, real-time, non-destructive and low-cost method for estimation of wheat quality. Based on the results, digital area is suitable to estimate aboveground biomass. Digital area outperformed other digital variables in biomass prediction in relation to stress, but height and Feret's diameter better correlated with yield and grain quality parameters. The developed technique is easy to use to assess the growth and health status of plants. An RGB digital camera is easy to operate and image acquisition can be done at will, meanwhile conventional laboratory instruments are relatively expensive, very expert-intensive and time consuming.

\section{Conclusion}

Our study showed that digital image analysis could be a viable alternate means for the real-time estimation of aboveground biomass and for predicting yield and grain quality parameters. We suggest that the combination of various vision-based methods could improve the estimation of wheat performance in a non-destructive and real-time way. The results also demonstrated that modern wheats had better yield production and grain quality compared to einkorn wheats, but the latter were not far behind, thus the cultivation of various species could provide a diverse and sustainable agriculture.

\section{Background}

Wheat is one of the most common crops in Hungary and in the European Union (Fig. 1., Eurostat 2019). Nowadays, in addition to winter wheat (Triticum aestivum L.), einkorn wheat (Triticum monococcum L. subs. monococcum) plays an increasingly important role in agriculture. A major goal for plant breeders is to develop more productive and less resourceintensive wheat varieties. Wild ancestors and ancient landraces represent an underexploited genetic resource in modern wheat breeding programs (Charmet 2011).

The earliest grain remains of wild einkorn were found in the Fertile Crescent in Karcadağ Mountains of South-East Turkey (Charmet 2011) and it spread in Europe from the Middle Ages until the early 20th century (Zaharieva \& Monneveux 2014). Einkorn completely disappeared from the Carpathian Basin during the 17th century, except in Transylvania, where its cultivation was maintained until the 20th century (Péntek \& Szabó 1981; Szabó 1976). Einkorn landraces evolved through genetic isolation under local environmental conditions, whereas high-bred races were created by strong human selection (Jacomet 2006). As a result of ecological adaptation, einkorn is tolerant to biotic and abiotic stress, resistant to diseases and pests, and has good nutritional value (Guzmán, Caballero \& Alvarez 2009; Hajnalová \& Dreslerová 2009), its reported protein content ranging between 13.2-28.5\% (Zaharieva \& Monneveux 2014). The reintroduction of its cultivation has been promoted by organic farming, because it provides low but acceptable yields on poor soils (Bencze et al. 2000; Castagna et 
al. 1995; Zaharieva \& Monneveux 2014). It has also been rediscovered as a healthy food, because according to new research, its gliadin is not so toxic to people with gluten intolerance (Charmet 2011, Zaharieva \& Monneveux 2014), although research is unconvincing as to whether ancient wheats are superior to all modern cultivars in reducing chronic diseases (Dinu et al. 2018).

The digital image analysis of plants is an increasingly popular and effective method for evaluating health in response to environmental stresses (Hu et al. 2010; Liu \& Pattey 2010). Image analysis methods are rapid, non-invasive and economical, and they operate with very high image resolution. These properties make it a viable alternative choice for realtime plant growth prediction (Yadav, Ibaraki \& Gupta 2010) and plant health assessment (Hu et al. 2010). Meanwhile, conventional analysis and destructive measurements are relatively expensive, labor-intensive, and time consuming methods (Hu et al. 2010; Suzuki \& Murase 2000).

Digital image analysis - based on an RGB camera - can be applied in agricultural research in various ways, because digital images contain a large amount of information. VIS sensors can be used to detect and monitor changes in plant structure, such as leaf orientation, plant height, and to determine crop status, growth status or biomass production (Berger, Parent \& Tester 2010; Fanourakis et al. 2014; Golzarian et al. 2011; Wang et al. 2014). Other researchers used image analysis to identify weeds (Hemming \& Rath 2001, Ahmad et al. 2006), to map weeds and crops (Tillet at al. 2001) and differentiation (Aitkenhead et al. 2003), to identify seed traits (Dana \& Ivo 2008, Gyulai et al. 2015), to estimate chlorophyll content and nitrogen concentration of leaves based on RGB features (Yadav, Ibaraki \& Gupta 2010; Wang et al. 2014). Hemming \& Rath (2001) and Suzuki \& Murase (2000) used shape features such as area, length/width and convexity for classification of broadleaf cabbage and carrots. Tillet et al. (1998) utilized size and shape features to rank crops. Golzarian \& Frick (2011) developed a vision-based method for separating wheat from common weed species using digital image processing techniques. Golbach et al. (2016) used digital image parameters (area, length, width, Feret's diameter) to measure specific features of leaf and stem and for phenotyping plants using a digital camera.

Aboveground biomass is a fundamental parameter for yield estimation, especially in the case of cover crops in precision agricultural management (Acorsi et al. 2019). The spectral features of vegetation depend on many variables, such as plant species, developmental stages, and physical and chemical properties of plants (e.g. nitrogen status). Nitrogen is one of the most important nutrients in the growth of crops and a major component of chlorophyll, which is associated with crop growth status and biomass production (Fageria, Baligar \& Jones 2011; Wang et al. 2014). Insufficient nitrogen supply results in less biomass production and reduces yield (Adhikari et al. 1999; Prasertsak \& Fukai 1997). The prediction of grain biomass production can be affected by many other factors, such as developmental stage, diseases, nutritional deficiencies and drought stress (Wang et al. 2014).

To facilitate the breeding of new wheat cultivars and improve the estimation of aboveground biomass, we studied two winter wheats and three einkorn wheats. Our questions are as follows: (i) Is there a difference between the cultivars in yield and in grain quality parameters? (ii) Is there a difference between digital image parameters according to cultivars, treatments and the date of recording? (iii) Is there a correlation between yield, grain quality parameters and digital image parameters of wheats? (iv) Can we estimate the aboveground biomass of wheats with a low-cost RGB camera based on a non-destructive digital images analysis method?

\section{Results}

\section{Yield and grain quality parameters of wheats}

According to the one-way Anova, cultivars had a strong significant effect on the yield and grain quality parameters: the strongest relationship was found between cultivars and gluten content $(F=205.978)$, but protein content $(F=142.210)$, yield $(F=127.961)$ and storage volume $(F=81.179)$ also had a significant relationship with cultivars. (Tab. A1). 
Based on Tukey's honest post hoc test, in the case of yield most cultivars differed significantly at the 0.001 level. (Tab. A2). Winter wheat Mv Magdaléna had the best yield among the studied cultivars, winter wheat Bánkúti1201 and einkorn wheat Bözödi had slightly lower yield, while einkorn wheat Mv Alkor and Schiemann had the lowest yield. Mv Magdaléna also had the best protein content, followed by Bánkúti1201 and Schiemann, then Mv Alkor, while Bözödi had the lowest protein content. Mv Magdaléna contained the highest amount of gluten, Bánkúti1201, Mv Alkor and Schiemann contained a similar, somewhat lower amount, and Bözödi had the lowest gluten content. The storage volume of Mv Magdaléna and Schiemann was the highest, Bözödi was similar to Schiemann, a lower storage volume was found for Mv Alkor, and the lowest for Bánkúti1201 (Table 1).

Table 1

Means of yield and grain quality parameters of the studied cultivars.

\begin{tabular}{|lllll|}
\hline Cultivars & Yield [t/ha] & Protein content [\%] & Gluten content [\%] & Storage volume [kg/hl] \\
\hline Mv Magdaléna & $6.1^{\mathrm{a}}$ & $13.4^{\mathrm{a}}$ & $31.8^{\mathrm{a}}$ & $81.4^{\mathrm{a}}$ \\
\hline Bankúti1201 & $4.5^{\mathrm{b}}$ & $12.5^{\mathrm{b}}$ & $23.6^{\mathrm{b}}$ & $75.7^{\mathrm{d}}$ \\
\hline Mv Alkor & $3.8^{\mathrm{c}}$ & $11.7^{\mathrm{c}}$ & $22.5^{\mathrm{b}}$ & $77.3^{\mathrm{c}}$ \\
\hline Schiemann & $3.5^{\mathrm{c}}$ & $12.6^{\mathrm{b}}$ & $25.8^{\mathrm{b}}$ & $80.1^{\mathrm{ab}}$ \\
\hline Bözödi & $4.4^{\mathrm{b}}$ & $9.3^{\mathrm{d}}$ & $15.4^{\mathrm{c}}$ & $79.1^{\mathrm{b}}$ \\
\hline Significant differences at p<0.001 based on Tukey's post hoc test are marked with different letters. \\
\hline
\end{tabular}

The Multivariate General Linear Model showed that all the fixed factors significantly affected all digital image parameters at the $p<0.05$ level (Tab. A3). Based on the number of significant interactions $-F$ value and partial $\eta^{2}-$ the strongest relationship with fixed factors was found for area. A strong or moderate relationship was observed between perimeter and recording date $\left(F=324.764\right.$; partial $\left.\eta^{2}=0.783\right)$ and perimeter and treatment $\left(F=76.335\right.$; partial $\left.\eta^{2}=0.459\right)$. Moderate relationships were found for height and recording date $\left(F=75.684\right.$; partial $\left.\eta^{2}=0.419\right)$, height and cultivar $(F=65.318$; partial $\left.\eta^{2}=0.592\right)$, Feret's diameter and recording date $\left(F=65.001\right.$; partial $\left.\eta^{2}=0.419\right)$ and Feret's diameter and cultivar $(F=$ 64.6; partial $\eta^{2}=0.589$ ). Width showed the weakest relationship with all the fixed factors.

The Univariate General Linear Model showed that all of the fixed factors and the interactions had a significant impact on area at level $p<0.001$ (Tab. A4). The fixed factors explained $91.8 \%$ of changes in area. According to Tukey's post hoc significant test, significant $(p<0.05)$ differences were found between all dates of recording and all treatments. As for the cultivars, Mv Magdaléna and Bánkúti1201 had significantly higher area than Mv Alkor, Schiemann and Bözödi (Tab. A5 A7). Area increased with time for all cultivars, as expected. Mv Magdaléna and Bánkúti1201 were significantly different from the other cultivars in the first two dates, but the growth of Mv Magdaléna slowed down by the third measurement and became similar to Mv Alkor, Schiemann and Bözödi (Fig. 2a). Drought had a negative impact on growth, resulting in a significantly lower area than control or nutrient deficiency with time (Fig. 2b). The cultivars reacted to stress in a slightly different way. Mv Magdaléna and Bánkúti1201 had significantly bigger area under drought than the other cultivars (Fig. 2c). Nutrient deficiency had no impact on growth with time compared to control, nor did the cultivars react to nutrient deficiency significantly.

\section{Correlation between yield, grain quality parameters and digital image parameters of wheats}


A moderate (up to $r=0.410)$ and highly significant $(p<0.001)$ positive correlation was observed between yield and the grain quality parameters. Out of the three grain quality parameters, protein and gluten content were the most strongly correlated $(r=0.935 ; p<0.001)$, gluten content and storage volume $(r=0.244 ; p<0.001)$ were moderately correlated, and no correlation was observed between protein content and storage volume.

All digital image parameters showed strong (area and perimeter, height and Feret's diameter; up to $r=0.918$ ) or moderate highly significant $(p<0.001)$ positive correlations with each other.

A moderate (up to $r=0.398)$ and highly significant $(p<0.001)$ positive correlation was found between yield, protein and gluten content compared to height or Feret's diameter. Correlation was positive, but lower (up to $r=0.199$ ) and less significant $(p<0.01)$ between yield, protein and gluten content compared to area or width. No correlation was found between yield, grain quality parameters compared to perimeter (Table 2). 
Table 2

Pearson's linear correlation between yield, grain quality parameters and digital image parameters of cultivars.

\begin{tabular}{|c|c|c|c|c|c|c|c|c|c|c|}
\hline & & Yield & $\begin{array}{l}\text { Protein } \\
\text { content }\end{array}$ & $\begin{array}{l}\text { Gluten } \\
\text { content }\end{array}$ & $\begin{array}{l}\text { Storage } \\
\text { volume }\end{array}$ & Area & Perimeter & Width & Height & $\begin{array}{l}\text { Feret's } \\
\text { diameter }\end{array}$ \\
\hline \multirow[t]{3}{*}{ Yield } & $\begin{array}{l}\text { Pearson } \\
\text { Correlation }\end{array}$ & 1 & & & & & & & & \\
\hline & $\begin{array}{l}\text { Sig. (2- } \\
\text { tailed) }\end{array}$ & & & & & & & & & \\
\hline & $\mathrm{N}$ & 225 & & & & & & & & \\
\hline \multirow[t]{3}{*}{$\begin{array}{l}\text { Protein } \\
\text { content }\end{array}$} & $\begin{array}{l}\text { Pearson } \\
\text { Correlation }\end{array}$ &, $246^{\star *}$ & 1 & & & & & & & \\
\hline & $\begin{array}{l}\text { Sig. (2- } \\
\text { tailed) }\end{array}$ & ,000 & & & & & & & & \\
\hline & $\mathrm{N}$ & 225 & 225 & & & & & & & \\
\hline \multirow[t]{3}{*}{$\begin{array}{l}\text { Gluten } \\
\text { content }\end{array}$} & $\begin{array}{l}\text { Pearson } \\
\text { Correlation }\end{array}$ &, $410^{\star \star}$ & $935^{\star *}$ & 1 & & & & & & \\
\hline & $\begin{array}{l}\text { Sig. (2- } \\
\text { tailed) }\end{array}$ & ,000 & ,000 & & & & & & & \\
\hline & $\mathrm{N}$ & 225 & 225 & 225 & & & & & & \\
\hline \multirow[t]{3}{*}{$\begin{array}{l}\text { Storage } \\
\text { volume }\end{array}$} & $\begin{array}{l}\text { Pearson } \\
\text { Correlation }\end{array}$ &, $305^{\star \star}$ & ,030 & $244^{\star \star}$ & 1 & & & & & \\
\hline & $\begin{array}{l}\text { Sig. (2- } \\
\text { tailed) }\end{array}$ & ,000 & 654 & ,000 & & & & & & \\
\hline & $N$ & 225 & 225 & 225 & 225 & & & & & \\
\hline \multirow[t]{3}{*}{ Area } & $\begin{array}{l}\text { Pearson } \\
\text { Correlation }\end{array}$ & $199^{\star \star}$ &, $170^{\star}$ &, $159^{\star}$ &,- 053 & 1 & & & & \\
\hline & $\begin{array}{l}\text { Sig. (2- } \\
\text { tailed) }\end{array}$ & ,003 & ,011 & ,017 & ,426 & & & & & \\
\hline & $\mathrm{N}$ & 225 & 225 & 225 & 225 & 225 & & & & \\
\hline \multirow[t]{3}{*}{ Perimeter } & $\begin{array}{l}\text { Pearson } \\
\text { Correlation }\end{array}$ & ,026 & 100 & 070 &,- 062 & $918^{\star *}$ & 1 & & & \\
\hline & $\begin{array}{l}\text { Sig. (2- } \\
\text { tailed) }\end{array}$ & ,703 & ,135 & ,295 & ,355 & ,000 & & & & \\
\hline & $\mathrm{N}$ & 225 & 225 & 225 & 225 & 225 & 225 & & & \\
\hline \multirow[t]{3}{*}{ Width } & $\begin{array}{l}\text { Pearson } \\
\text { Correlation }\end{array}$ &, $196^{\star *}$ &, $136^{\star}$ &, $164^{\star}$ & ,080 &, $619^{\star \star}$ &, $605^{\star \star}$ & 1 & & \\
\hline & $\begin{array}{l}\text { Sig. (2- } \\
\text { tailed) }\end{array}$ & ,003 & ,042 & ,014 & ,231 & ,000 & ,000 & & & \\
\hline & $\mathrm{N}$ & 225 & 225 & 225 & 225 & 225 & 225 & 225 & & \\
\hline \multirow[t]{2}{*}{ Height } & $\begin{array}{l}\text { Pearson } \\
\text { Correlation }\end{array}$ &, $383^{\star *}$ &, $358^{\star \star}$ &, $398^{\star \star}$ & ,045 & $694^{\star \star}$ &, $643^{\star \star}$ &, $529^{\star \star}$ & 1 & \\
\hline & $\begin{array}{l}\text { Sig. (2- } \\
\text { tailed) }\end{array}$ & ,000 & ,000 & ,000 & ,501 & ,000 & ,000 & ,000 & & \\
\hline
\end{tabular}




\begin{tabular}{|c|c|c|c|c|c|c|c|c|c|c|}
\hline & & Yield & $\begin{array}{l}\text { Protein } \\
\text { content }\end{array}$ & $\begin{array}{l}\text { Gluten } \\
\text { content }\end{array}$ & $\begin{array}{l}\text { Storage } \\
\text { volume }\end{array}$ & Area & Perimeter & Width & Height & $\begin{array}{l}\text { Feret's } \\
\text { diameter }\end{array}$ \\
\hline & $\mathrm{N}$ & 225 & 225 & 225 & 225 & 225 & 225 & 225 & 225 & \\
\hline \multirow[t]{3}{*}{$\begin{array}{l}\text { Feret's } \\
\text { diameter }\end{array}$} & $\begin{array}{l}\text { Pearson } \\
\text { Correlation }\end{array}$ &, $387^{\star \star}$ &, $345^{\star \star}$ &, $392^{* *}$ & ,062 &, $685^{\star \star}$ &, $617^{\star \star}$ &, $649^{* *}$ &, $948^{\star \star}$ & 1 \\
\hline & $\begin{array}{l}\text { Sig. (2- } \\
\text { tailed) }\end{array}$ & ,000 & ,000 & ,000 & ,358 & ,000 & ,000 & ,000 & ,000 & \\
\hline & $\mathrm{N}$ & 225 & 225 & 225 & 225 & 225 & 225 & 225 & 225 & 225 \\
\hline
\end{tabular}

${ }^{* *}$ Correlation is significant at the 0.01 level (2-tailed), ${ }^{*}$ Correlation is significant at the 0.05 level (2-tailed). If $r=1$ : perfect positive correlation, $0.7 \leq r<1$ : strong positive correlation, $0.2 \leq r<0.7$ : moderate positive correlation, $0<r<0.2$ weak positive correlation.

\section{Discussion}

\section{Comparison of modern and ancient wheats based on yield and grain quality parameters}

Although the number of comparative studies about modern and ancient types of wheats is increasing, there are still relatively few research groups working in this area (Shewry 2018). According to the study of Morris \& Sands (2003) modern bread wheat differs in composition and in health benefits from traditional types of wheats, but these differences have not been confirmed by detailed analysis (Dinu et al. 2018; Shewry et al. 2011; Riberio et al. 2016).

The main aim of the breeding programs involving modern cultivars was to increase grain yield (Mefleh et al. 2018). Despite the lower yield of ancient and traditional wheats, they provide an acceptable yield under low-input management. Furthermore, their advantage lies also in good ecological adaptation, such as tolerance to biotic and abiotic stress, and resistance to diseases (Guzmán, Caballero \& Alvarez 2009, Hajnalová \& Dreslerová 2009, Zaharieva \& Monneveux 2014). Our study shows that modern wheats have better yield production compared to traditional and ancient wheats, but the latter are not far behind. Although modern winter wheat Mv Magdaléna had the best yield (6.1 t/ha) among the studied cultivars, traditional winter wheat Bánkúti1201 and the three einkorns had acceptable yields (from 3.5 to 4.5 t/ha) for organic farming. The grain yields obtained in the present work are in line with the Hungarian study of Bencze et al. (2020) where the yields of einkorn landraces were around $3 \mathrm{t} / \mathrm{ha}$. In other European countries (e.g. Italy) 0.84-4.5 t/ha yields were recorded for einkorn (Castagna et al. 1995). The average yield and grain quality was satisfactorily high both in bread wheat and in einkorn wheat, although the impact of the genotypes and environmental factors should also be investigated in the future.

Zaharieva \& Monneveux (2014) and Boxstael et al. (2020) revealed that the nutritional value of ancient wheats is excellent. In our study the modern wheat Mv Magdaléna achieved the highest protein content (13.4\%), followed by Schiemann (12.6\%), Bánkúti1201 (12.5\%), Mv Alkor (11.7\%) and Bözödi (9.3\%). Our results correspond to the findings of Bencze et al. (2020), who revealed that the grain protein content of einkorn Mv Alkor was less than $15 \%$. In contrast Hidalgo \& Brandolini (2014) and Hidalgo et al (2009) reported higher total proteins (15-25\%, on average + 59\%) in einkorn wheat than in bread wheat.

Gluten intolerance is a widespread problem nowadays (Charmet 2011, Zaharieva \& Monneveux 2014), and this is the other reason why ancient wheats are being rediscovered as a healthy food. We found that all of the studied einkorns had significantly lower gluten content than winter wheats: Bözödi 15.4\%; Mv Alkor 22.5\%; Schiemann 25.8\% compared to Bánkúti1201 23.6\% and Mv Magdaléna 31.8\%. In general, einkorn gluten content has poor bread manufacturing properties, 
nevertheless einkorn flour is ideal for preparation of healthy cookies and gives good-quality pasta (Brandolini \& Hidalgo 2011).

The impact of cultivars, treatments and the date of recording on biomass production based on digital image analysis

The only treatment with a significant negative impact on growth was drought stress, resulting in a much slower increase in biomass over time compared to control and nutrient deficiency specimens. Among the studied cultivars winter wheats performed best in both growth and resistance to drought stress. Although several studies (Guzmán, Caballero \& Alvarez 2009; Hajnalová \& Dreslerová 2009; Zaharieva \& Monneveux 2014) found that einkorn wheats were highly resistant to environmental stresses, we, on the contrary, have found that the studied einkorns responded worse to drought stress than winter wheats. Mv Magdaléna and Bánkúti1201 had significantly higher biomass production under drought stress than the three einkorn wheats: Mv Alkor, Schiemann and Bözödi. The cultivars did not react significantly to nutrient deficiency, and nutrient deficiency had no impact on biomass production either compared to control. The reason for this can be that the experiment was conducted during the tillering stage, and abiotic stresses are known to be critical and to cause yield loss in the subsequent reproductive phases of growth, mainly in the grain filling phase (Sehgal et al. 2018), hence further studies are required regarding the reproductive stage.

\section{Comparison of yield, grain quality parameters and digital image parameters for wheat quality estimation}

Analysis of digital data of wheat canopy can provide important indicators on growth variability and help understand yield and grain quality parameters influencing wheat quality. Several techniques have been developed to estimate yield based on plant biomass in different crops. According to the studies of Bendig et al. 2014; Iqbal et al. 2017 and Golbach et al. 2016 plant height or Feret's diameter could be used for estimating crop structure parameters and for predicting aboveground biomass. Biomass was positively correlated with grain yield in the case of maize (Li et al. 2015); spring wheat (Fischer 1993); spring barley (Boukerrou and Rasmusson 1990, Bendig et al. 2014); and black oat (Acorsi et al. 2019).

Nevertheless, to our knowledge no study has explored the relation of the aboveground biomass, yield and grain quality parameters together, therefore we compared and analysed this information together. A moderate and highly significant positive correlation was observed between the yield and the grain quality parameters, as expected. We found a moderate and highly significant correlation between the height and Feret's diameter of cultivars extracted from the images compared to yield, protein and gluten content. Meanwhile area was less correlated and had less significance relating to the same quality attributes. Our findings imply that height and Feret's diameter are good indicators to predict not only the aboveground biomass production, but the yield and grain quality parameters as well.

\section{The improvement of non-destructive estimation of aboveground biomass}

Aboveground biomass is a widely used agronomic indicator for characterizing crop growth status and predicting grain yield (Acorsi et al. 2019; Lu et al. 2019). The estimation of aboveground biomass in a non-invasive way is an important task in assessing crop nitrogen status and in the development of precision farming (Lu et al. 2019; Tilly et al. 2015). Previous studies showed that canopy cover estimated from the images was highly correlated with aboveground biomass (Lee \& Lee 2013) and was also stable in varying environmental conditions (Liu \& Pattey 2010).

One purpose was to develop a low-cost and simple method for assessing real-time aboveground biomass production and for estimating stress factors based on RGB image analysis. Therefore, we calculated the number of pixels on the projecting area and other digital image parameters under nutrient deficiency and drought stress. Among the studied parameters, digital area was the most important predictor variable, although digital perimeter also estimated plant growth and drought stress well. Our results show that by segmenting the images and measuring the projected area it is possible to assess the 
plant growth of wheats, which is related to biomass production and drought stress. This outcome corresponds to the finding of Khun et al. (2018), who revealed that plant area is correlated to biomass production and with different digital image parameters could predict the phasic development and phenotypic traits of wheats.

Our results suggest that the use of combined information would provide better performance for estimating wheat quality than the use of a single indicator, in our case the digital area. Area responded the best as an indicator of wheat growth under experimental stress conditions, meanwhile height and Feret's diameter better signaled yield and grain quality parameters. The results can be useful in predicting the quality of wheats, with potential uses in improving the management of precision farming.

\section{Conclusions}

This study investigated the modern and ancient types of wheats combining field estimation and laboratory stress study with VIS-based digital image analysis. Based on our results both winter wheat and einkorn wheat can be grown successfully under low-input organic farming and still keep their yield and quality. The cultivation of various species could provide a more diverse and sustainable agriculture, instrumental in adapting to climate change. Further research is still required, particularly on a wider range of genotypes of traditional, ancient and modern wheat cultivars.

The VIS-based digital image analysis demonstrated that digital area outperformed other digital variables in biomass prediction in relation to laboratory stress experiment, but height and Feret's diameter outperformed area in the prediction of yield and grain quality parameters. Based on these results we suggest that the combination of various VIS-based methods could improve the estimation of wheat performance in a non-destructive and real-time way. We conclude that use of digital morphological parameters could be an alternative choice for the real-time prediction of aboveground biomass production and the detection of drought stress in wheats in several different developmental stages. The developed method is a rapid, non-invasive and lower-cost technique that is easy to use to assess the growth and health status of plants. An RGB digital camera is easy to operate and image acquisition can be done at will, meanwhile conventional laboratory instruments are relatively expensive, very expert-intensive and time consuming.

Vision-based image analysis methods have showed acceptable and precise prediction under controlled light conditions, but further validation is necessary to ensure their application in the field. Hence standard controlled processes need to be developed to make them acceptable in proper agricultural application.

\section{Methods}

To facilitate the development of new wheat cultivars and improve the digital estimation of aboveground biomass, we studied two winter wheats (Mv Magdaléna and Bánkúti1201) and three einkorn wheats (Mv Alkor, Bözödi, Schiemann) with the latest technologies, including a field study (uncontrolled conditions), a laboratory stress experiment (controlled conditions) and vision-based (VIS-based) digital image analysis. Yield was measured in the field, grain quality was measured after cultivation and harvest with a near infrared optical laboratory analyser for fast and precise qualification. In order to predict biomass production under different stress conditions, seedlings were grown in a phytotron under three kinds of treatments (control, nutrient deficiency, drought stress) for 30 days and biomass production was estimated with an RGB camera. Modern VIS-based digital image analysis was used for data processing. To combine data drawn both from controlled and uncontrolled experiments, biomass, yield and grain quality parameters were analysed side by side.

\section{Plant material}

We investigated two different winter wheat cultivars and three different einkorn wheat cultivars: (i) Mv Magdaléna is a registered Hungarian winter wheat cultivar with hard endosperm structure and high gluten and protein content. It has excellent milling grade quality (MTA ATK 2014). Seeds were offered by the Agricultural Institute, Centre for Agricultural 
Research (Martonvásár, Hungary). (ii) Bánkúti 1201 is an old Hungarian winter wheat cultivar with average or slightly better yield potential, hard endosperm structure and good rheological properties. It also has satisfactory climatic resistance and extremely good drought tolerance (Balla et al. 2013; Juhász et al. 2003). Seeds were provided by the Research Institute of Organic Agriculture (ÖMKi, Budapest, Hungary). (iii) Mv Alkor is a registered Hungarian winter einkorn cultivar, used in extensive organic farming, has medium yield, but high protein and fiber content. Mv Alkor has good weed-suppressing ability, is drought tolerant and resistant to fungal diseases (MTA ATK 2014). Seeds were offered by the Agricultural Institute, Centre for Agricultural Research (Martonvásár, Hungary). (iv) Schiemann einkorn is from Morocco, and is registered in the Hungarian Gene Bank (NöDiK, code RCAT 074129), the seeds came from NöDiK. (v) The Bözödi einkorn landrace originates from the sub-mountainous regions of Transylvania (Romania), cultivated under traditional farming practices. It is an excellent genetic source with high nutritional value (Hajnalová \& Dreslerová 2009). The re-introduction of its cultivation was promoted by organic farming. Seeds were provided by the Plant Diversity Centre (NöDiK, Tápiószele, Hungary).

\section{Analysis of yield and grain quality parameters}

In 2016, the three einkorn wheats and winter wheat Bánkúti1201 were sown in the field, winter wheat Mv Magdaléna was not sown due to lack of seeds. The $1 \mathrm{~m} \times 9 \mathrm{~m}$ experimental plots were placed in four replicates in Nagygombos, rented by the Institute of Plant Production of Szent István University. After harvest, the (i) yield of each wheat was measured in the field and calculated per hectare. The grains with glume were hulled with Santec SRO VKI11 laboratory huller in a laboratory to prepare samples for measuring grain quality parameters. (ii) Protein and (iii) gluten content were measured in four repetitions with a Mininfra-ScanT Plus near infrared optical analyser at wavelengths ranging between $790 \mathrm{~nm}$ and 1064 $\mathrm{nm}$. The (iv) storage volume of grains was measured in a laboratory glass in four replicates. For the parameters of $\mathrm{Mv}$ Magdaléna, we relied on the data of the national catalogue of registered field crops.

\section{Experimental design of controlled stress}

The stress experiment was conducted at Szent István University, Faculty of Agricultural and Environmental Sciences, Department of Genetic and Plant Breeding in Gödöllő and at the Agricultural Institute, Centre for Agricultural Research in Martonvásár in 2017. The experiment was performed under controlled light conditions, reducing the effect of light on the image.

The plants were developed in Jiffy peat pots for 43 days in an unheated greenhouse from 16 September. After 43 days, the seedlings were planted in round pots in a 3:2:1 mixture of $2800 \mathrm{~cm}^{3}$ of garden soil, compost and sand. The pots were placed in a Conviron PGR-15 phytotron spring/summer growth chamber offering a growth area of $1.5 \mathrm{~m}^{2}$ and a growth height of $1450 \mathrm{~mm}$.

Three different treatments were implemented in our study: control (C), nutrient deficiency (ND), and drought stress (DS) during the tillering development stage. Control plots were watered daily with tap water and supplemented once a week with Wuxal Super nutrient solution. The nutrient deficient pots were watered daily with tap water without extra nutrients. Drought stress plots were watered twice a week for 13 days and once a week for 17 days with tap water supplemented with the same nutrient solution as the control. All treatments were performed in five replicates, each cultivar was represented by 15 plots and the treatments were applied for 30 days. The night/day temperature was maintained at $10 / 15^{\circ} \mathrm{C}$ for 11 days. For an additional 19 days, the night/day temperature was kept at $13 / 17^{\circ} \mathrm{C}$, illuminated with halogen lamps for 12 hours per day. The average air humidity was $75 \%$ during the night and $65 \%$ during the day.

\section{Digital image acquisition and processing}

To measure the growth parameters of winter wheat and einkorn cultivars, the aboveground part of the plants was photographed three times $(9,18,26$ November 2017) after being transplanted from Jiffy into the pots in the early stage of plant growth. The plants were placed in front of a white background and illuminated with halogen bulbs. Digital images 
were taken of the central zone of the canopy with a Canon EOS 30D DSLR digital still color camera (2009 Canon Inc., Japan) with 8.2 megapixel resolution. Data was recorded in RAW format, intensity data was digitalized to 12 bits. The camera was mounted on a tripod, and the distance from the camera tripod to the subject was constantly $3.2 \mathrm{~m}$. The digital camera settings were as follows: exposure time $1 \times 10^{-2}$, aperture f/10, ISO 100, focal length $50 \mathrm{~mm}$, white balance with $4900 \mathrm{~K}$, flash turned off.

All images in the experiment were stored in CR2 (Canon RAW image file) format. The RAW format contains minimally processed data from image sensors in a digital camera, the file contains white balance, saturation, contrast and sharpness settings, but delays processing. Therefore, all changes made to the RAW image file are non-destructive (Wang et al. 2014). The images were processed with Adobe Photoshop CC 20.04.4 software (Adobe Systems Inc., USA). The processing was performed by the image segmentation feature of the Camera RAW 11.2 plug-in. The canopy was separated from the white background and from the other surfaces, which is important for the accurate estimation of biomass production. The processed images were saved in 16-bit TIFF uncompressed format (Fig. 3).

\section{Acquisition of digital image parameters}

The images were analysed for biomass phenotyping under controlled conditions based on the projected area of the plant in the image. Image parameters were determined with the open source software ImageJ (Ferreira \& Rasband 2012). In the RGB stack, the color threshold was adjusted according to the intermodes thresholding method. Red was selected as the threshold color in HSB color space. The method is based on the appropriate contrast between the plant and the background. The object was separated/filtered from the background pixels based on contrast (Fig. 4). Pixels representing biomass are suitable for quantification and analysis. The percentage of object pixels relative to the pixels of the entire area of the visual image - called the Projected Area - was measured. The following parameters were calculated in thresholded images: (i) area: area of composite selection, ignoring pixels outside the object; values were expressed in square pixels; (ii) perimeter: the length of the outer boundary of the composite selection; bounding rectangle: the smallest (iii) width and (iv) height enclosing the selection; (v) Feret's diameter: the maximum distance between any two points along the selection boundary, also known as the maximum caliper (Ferreira \& Rasband 2012). The latter four parameters were expressed in pixels.

\section{Data analysis}

To detect differences in yield and in grain quality parameters between the cultivars, we used the one-way Anova statistical method with Tukey's honest post hoc significant test. The dependent variables were the yield and grain quality parameters and the fix factor was the type of cultivar. The mean difference was considered significant at the 0.001 probability level.

To find the interaction between digital image parameters and cultivars, treatments and time, we selected the most informative dependent variable by Multivariate General Linear Model (Multivariate Anova/Manova) as a first step. The dependent variables were area, perimeter, bounding rectangle (width and height) and Feret's diameter. The fixed factors were the five wheat cultivars (Mv Magdaléna, Bánkúti1201, Mv Alkor, Schiemann and Bözödi), the three treatments (control, nutrient deficiency and drought stress), and the dates of RGB measurements (9, 18, 26 November 2017) with all possible interactions included (cultivars*treatment, cultivars*date, treatment*date, cultivars*treatment*date). In a second step, the dependence of the selected digital image parameter (dependent variable) on cultivars, treatments, dates and interactions (fixed factors) was tested by Univariate General Linear Model (Multiway/Multiple Anova). Differences within the main factors, within date differences between cultivars and treatments and within treatment differences between cultivars were tested with Tukey's honest post hoc test, significance was considered at the 0.05 probability level.

To determine significant correlations between yield, grain quality parameters (protein and gluten content, storage volume) and digital image parameters (area, perimeter, width, height, Feret's diameter) of cultivars, Pearson's correlation formula 
was used with a two-tailed test at the $\mathrm{p}<0.05$ or $\mathrm{p}<0.01$ probability level.

All datasets were managed using the MS Excel 2016 software. Statistical analysis and production of graphs was performed using the IBM SPSS Statistics 17.0 software.

\section{Declarations}

\section{Ethics approval and consent to participate}

Not applicable.

\section{Consent for publication}

Not applicable.

\section{Availability of data and materials}

The image datasets used and analysed during the current study are available from the corresponding author on reasonable request.

\section{Competing interest}

The authors declare that they have no competing interests.

\section{Funding}

This work was funded by the ÚNKP-17-3 New National Excellence Program of the Ministry of Human Capacities. ECs was supported by the Human Capacities Grant Management Office (NTP-NFTÖ-20-B-0048 grant).

\section{Authors' contributions}

All authors contributed to this project. JB, ECs and FGy conceived and designed the study. AE and CsE pre-processed the images. ECs and $\mathrm{MH}$ analysed the data. ECs and $\mathrm{MH}$ wrote the article. All authors read and approved the final manuscript.

\section{Acknowledgements}

The authors would like to thank the suppliers of the seeds: Agricultural Institute, Centre for Agricultural Research (MTA ATK Martonvásár); Research Institute of Organic Agriculture (ÖMKi Budapest); Hungarian Gene Bank (NöDiK, Tápiószele). The authors are grateful to the Institute of Plant Production of Szent István University for the help in the field experiment.

\section{References}

Acorsi, Matheus G.; das Dores Abati Miranda, Fabiani; Martello, Maurício; Smaniotto, Danrley A.; Sartor, Laercio R. 2019. "Estimating Biomass of Black Oat Using UAV-Based RGB Imaging." Agronomy 9, no. 7: 344.

https://doi.org/10.3390/agronomy9070344

Adhikari C, Bronson KF, Panuallah GM, Regmi AP, Saha PK, Dobermann A, Olk DC, Hobbs PR, Pasuquin E: On-farm soil N supply and N nutrition in the rice-wheat system of Nepal and Bangladesh. Field Crops Res 1999, 64:273-286.

Ahmad I, Muhamin A, Naeem Islam M (2006) Real-time specific weed recognition system using histogram analysis. Proc World Acad Sci Eng Technol 16:1307-6884

Aitkenhead MJ, Dalgetty IA, Mullins CE, Mc Donald AJS, St Rachan NJC (2003) Weed and crop discrimination using image analysis and artificial intelligence methods. Comput Electron Agric 39:157-171 
Balla, Krisztina \& Karsai, Ildikó \& Bencze, Szilvia \& Kiss, Tibor \& Veisz, Ottó. (2013). Effect of heat stress on the physiological processes of wheat. Acta Agronomica Hungarica. 61. 1-12. 10.1556/AAgr.61.2013.1.1.

Boukerrou, L.; Rasmusson, D.D. Breeding for high biomass yield in Spring Barley. Crop Sci. 1990, 30, 31-35.

Van Boxstael F, Aerts H, Linssen S, Latré J, Christiaens A, Haesaert G, Dierickx I, Brusselle J, De Keyzer W. A comparison of the nutritional value of Einkorn, Emmer, Khorasan and modern wheat: whole grains, processed in bread, and populationlevel intake implications. J Sci Food Agric. 2020 Aug 30;100(11):4108-4118. doi: 10.1002/jsfa.10402. Epub 2020 May 4. PMID: 32246458.

Brandolini A and Hidalgo A, Einkorn (Triticum monococcum) flour and bread, in Flour and breads and their fortification in health and disease prevention ed. by Preedy VR, Watson RR and Patel VB. Academic Press, Elsevier, London, Burlington, San Diego, pp. 79-88 (2011)

Bencze, S.; Makádi, M.; Aranyos, T.J.; Földi, M.; Hertelendy, P.; Mikó, P.; Bosi, S.; Negri, L.; Drexler, D. Re-Introduction of Ancient Wheat Cultivars into Organic Agriculture-Emmer and Einkorn Cultivation Experiences under Marginal Conditions. Sustainability 2020, 12, 1584. https://doi.org/10.3390/su12041584

Bendig J, Bolten A, Bennertz S, Broscheit J, Eichfuss S, Bareth G. Estimating biomass of barley using crop surface models (CSMs) derived from UAVbased RGB imaging. Remote Sens. 2014;6(11):10395-412.

Berger B, Parent B, Tester M: High-throughput shoot imaging to study drought responses. J Exp Bot 2010, 61:3519-3528.

Castagna, R.; Borghi, B.; Di Fonzo, N.; Heun, M.; Salamini, F. Yield and related traits of einkorn (T. monococcum ssp. monococcum) in different environments. Eur. J. Agron. 1995, 4, 371-378. [CrossRef]

Charmet G. (2011): Wheat domestication: Lessons for the future. In: Comptes Rendus Biologies 334 (2011): 212 - 220. , ScienceDirect.

Dana W, Ivo W (2008) Computer image analysis of seed shape and seed color of flax cultivar description. Comput Electron Agric 61:126-135

Dinu, M., Whittaker, A., Pagliai, S., Sofi, F., 2018. Ancient wheat species and human health: biochemical and clinical implications. J. Nutr. Biochem. 52, 1 e9.

Eurostat 2020. https://ec.europa.eu/eurostat/web/products-datasets/-/tag00047

Fageria NK, Baligar VC, Jones CA: Growth and Mineral Nutrition of Field Crops. 3rd edition. Boca Raton: CRC Press; 2011.

Fanourakis D, Briese C, Max JF, Kleinen S, Putz A, Fiorani F, Ulbrich A, Schurr U: Rapid determination of leaf area and plant height by using light curtain arrays in four species with contrasting shoot architecture. Plant Methods 2014, 10:9.

Ferreira, T. and Rasband, W. (2012) ImageJ User Guide-IJ1.46r. http://imagej.nih.gov/ij/docs/guide

Fischer, R.A. Irrigated spring wheat and timing and amount of nitrogen fertilizer. II. Physiology of grain yield response. Field Crops Res. 1993, 33, 57-80.

Golbach, F., Kootstra, G., Damjanovic, S. et al. Validation of plant part measurements using a 3D reconstruction method suitable for high-throughput seedling phenotyping. Machine Vision and Applications 27, 663-680 (2016). https://doi.org/10.1007/s00138-015-0727-5 
Golzarian, M.R., Frick, R.A. Classification of images of wheat, ryegrass and brome grass species at early growth stages using principal component analysis. Plant Methods 7, 28 (2011). https://doi.org/10.1186/1746-4811-7-28

Golzarian MR, Frick RA, Rajendran K, Berger B, Roy S, Tester M, Lun DS: Accurate inference of shoot biomass from highthroughput images of cereal plants. Plant Methods 2011, 7:1-11.

Guzmán C., Caballero L., Alvarez J. B. (2009): Variation in Spanish cultivated einkorn wheat (Triticum monococcum L. ssp. monococcum) as determinated by morphological traits and waxy proteins. In: Genet Resour Crop Evol (2009) 56:601-604., Springer Science+Business Media.

Gyulai G., Rovner I., Vinogradov S., Kerti B., Emődi A., Csákvári E., Kerekes A., Mravcsik Z., Gyulai F. (2015): Digital seed morphometry of dioecious wild and crop plants - development and usefulness of the seed diversity index. In: Hay F. (szerk.). Seed Science and Technology 43 (3) pp. 1-15. ISSN 0251-0952. https://doi.org/10.15258/sst.2015.43.3.15

Hajnalová M., Dreslerová D. (2010): Ethnobotany of einkorn and emmer in Romania and Slovakia: towards interpretation of archeological evidence. In: Památky Archeologické Cl: 169 - 202.

Hemming J, Rath T: Computer-Vision-based Weed Identification under Field Conditions using Controlled Lighting. Journal of Agricultural Engineering Research 2001, 78:233-243.

Hidalgo, A.; Brandolini, A.; Ratti, S. Influence of genetic and environmental factors on selected nutritional traits of Triticum monococcum. J. Agric. Food Chem. 2009, 57, 6342-6348.

Hidalgo, A. and Brandolini, A. (2014), Nutritional properties of einkorn wheat (Triticum monococcum L.). J. Sci. Food Agric., 94: 601-612. https://doi.org/10.1002/jsfa.6382

Hu, Hao \& Liu, He-qin \& Zhang, Hao \& Zhu, Jing-huan \& Yao, Xu-guo \& Zhang, Xiao-bin \& Zheng, Ke-feng. (2010). Assessment of Chlorophyll Content Based on Image Color Analysis, Comparison with SPAD502. 2nd International Conference on Information Engineering and Computer Science - Proceedings, ICIECS 2010. 1-3.

10.1109/ICIECS.2010.5678413.

Iqbal F, Lucieer A, Barry K, Wells R. Poppy crop height and capsule volume estimation from a single UAS flight. Remote Sens. 2017;9(7):647.

Jacomet S. (2006): Identification of cereal remains from archeological sites. Archeobotany Lab, IPAS, Basel University, 61p.

Juhász A, Larroque OR, Tamás L, Hsam SL, Zeller FJ, Békés F, Bedo Z. Bánkúti 1201-an old Hungarian wheat variety with special storage protein composition. Theor Appl Genet. 2003 Aug; 107(4):697-704. doi: 10.1007/s00122-003-1292-2. Epub 2003 May 16. PMID: 12750774.

Khun K., Vigneault P., Fallon E., Tremblay N., Codjia C., Cavayas F. 2018. Estimating Corn Biomass from RGB Images Acquired with an Unmanned Aerial Vehicle. 14th International Conferencr on Precision Agriculture June 24 - June 27, 2018, Montreal, Quebec, Canada.

Lee K-J, Lee B-W: Estimation of rice growth and nitrogen nutrition status using color digital camera image analysis. Eur $\mathrm{J}$ Agron 2013, 48:57-65.

Li, W.; Niu, Z.; Huang, N.; Wang, C.; Gao, S.; Wu, C. Airborne lidar technique for estimating biomass components of maize: A case study in Zhangye City, Northwest China. Ecol. Indic. 2015, 57, 486-496.

Liu J, Pattey E: Retrieval of leaf area index from top-of-canopy digital photography over agricultural crops. Agric For Meteorol 2010, 150:1485-1490.

Page $14 / 18$ 
Lu, N., Zhou, J., Han, Z. et al. Improved estimation of aboveground biomass in wheat from RGB imagery and point cloud data acquired with a low-cost unmanned aerial vehicle system. Plant Methods 15, 17 (2019).

https://doi.org/10.1186/s13007-019-0402-3

Mefleh, M., Conte, P., Fadda, C., Giunta, F., Piga, A., Hassoun, G. and Motzo, R. (2019), From ancient to old and modern durum wheat varieties: interaction among cultivar traits, management, and technological quality. J. Sci. Food Agric., 99 : 2059-2067. https://doi.org/10.1002/jsfa.9388

Morris, C.E., Sands, D.C., 2003. The breeder's dilemma - yield or nutrition? Nat.

Biotechnol. 24, 1078e1080.

MTA ATK 2014-2015. Martonvásári fajtakatalógus. MTA ATK Mezőgazdasági Intézet.

Péntek J., Szabó T. A. (1981): Az alakor (Triticum monococcum) Erdélyben. In: Ethnographia XCII 2 - 3: 259 - 277.

Prasertsak A, Fukai S: Nitrogen availability and water stress interaction on rice growth and yield. Field Crops Res 1997, 52:249-260.

Ribeiro, M., Rodroguez-Quijano, M., Nunes, F.M., Carillo, J.M., Branlard, G., Igrejas, G. 2016. New insights into wheat toxicity: breeding does not seem to contribute to a prevalence of potential celiac disease's immunostimulatory epitopes. Food Chem. 213, 8e18.

Peter R. Shewry, Do ancient types of wheat have health benefits compared with modern bread wheat?, Journal of Cereal Science, Volume 79, 2018, Pages 469-476, ISSN 0733-5210, https://doi.org/10.1016/j.jcs.2017.11.010.

Sehgal A, Sita K, Siddique KHM, Kumar R, Bhogireddy S, Varshney RK, HanumanthaRao B, Nair RM, Prasad PVV, Nayyar H. Drought or/and Heat-Stress Effects on Seed Filling in Food Crops: Impacts on Functional Biochemistry, Seed Yields, and Nutritional Quality. Front Plant Sci. 2018 Nov 27;9:1705. doi: 10.3389/fpls.2018.01705. PMID: 30542357; PMCID:

PMC6277783.

Shewry, P.R., Gebruers, K., Andersson, A.A.M., Aman, P., Piironen, V., Lampi, A.-M., Boros, D., Rakszegi, M., Bedo, Z., Ward, J.L., 2011. Relationship between the contents of bioactive components in grain and the release dates of wheat lines in the healthgrain diversity screen. J. Agric. Food Chem. 59, 928 e933.

Suzuki, T., Murase, H. 2000. Non-destructive growth measirement by mechine vision for cabbage plug seedlings population with missing platnts. IFAC Bio-Robotics, Information Technology and Intelligent. Control for Bio-Production System, Sakai, Osaka, Japan.

Szabó T. A. (1976): On the borderline of natural science and ethnology. In: Kriterion Verlag, Bucaresti, pp. 36 - 40.

Tillett ND, Hague T, Marchant JA: A robotic system for plant-scale husbandry. Journal of Agricultural and Engineering Research 1998, 69:169-178

Tillet NP, Hague T, Miles SJ (2001) A field assessment of a potential method for weed and crop mapping geometry. Comput Electron Agric 32:229-246

Yadav, S.P., Ibaraki, Y. \& Dutta Gupta, S. Estimation of the chlorophyll content of micropropagated potato plants using RGB based image analysis. Plant Cell Tiss Organ Cult 100, 183-188 (2010). https://doi.org/10.1007/s11240-009-9635-6

Yuzhu, Han. (2011). Nitrogen determination in pepper (Capsicum frutescens L.) plants by color image analysis (RGB). AFRICAN JOURNAL OF BIOTECHNOLOGY. 10. 10.5897/AJB11.1974.

Page 15/18 
Zaharieva M., Monneveux P. (2014): Cultivated einkorn wheat (Triticum monococcum L. subsp. monococcum): the long life of a founder crop of agriculture. In: Genetic Resource and Crop Evolution (2014). Volume 61, Issue 3, pp. 677-706., Springer Science+Business Media.

Wang, Y., Wang, D., Shi, P., Omasa K. Estimating rice chlorophyll content and leaf nitrogen concentration with a digital still color camera under natural light. Plant Methods 10, 36 (2014). https://doi.org/10.1186/1746-4811-10-36

\section{Figures}

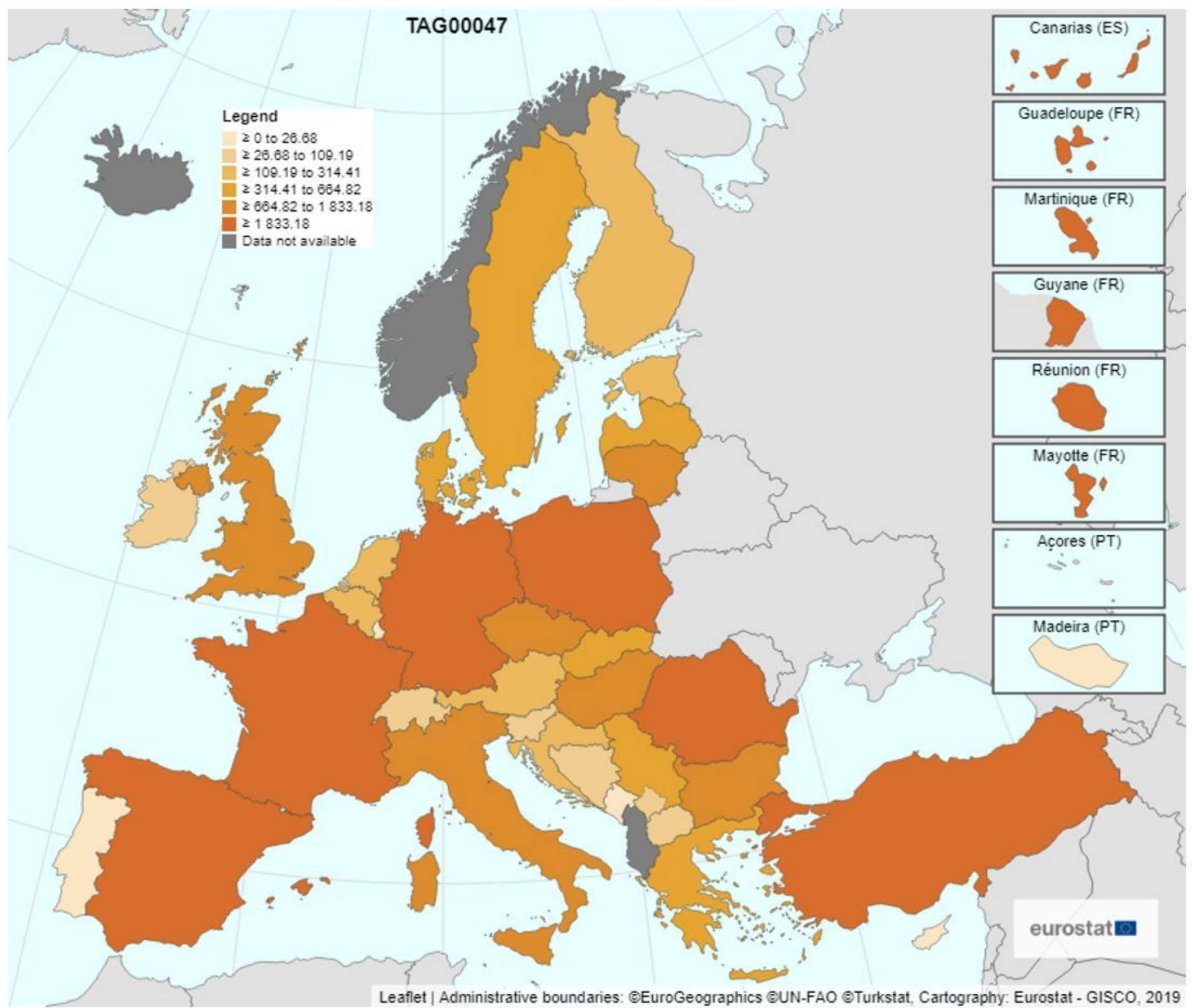

\section{Figure 1}

Common wheat, spelt, einkorn wheat and durum wheat by area, production (1000 ha) and humidity in the European Union, 2019 (Eurostat 2020). Note: The designations employed and the presentation of the material on this map do not imply the expression of any opinion whatsoever on the part of Research Square concerning the legal status of any country, territory, 
city or area or of its authorities, or concerning the delimitation of its frontiers or boundaries. This map has been provided by the authors.

a

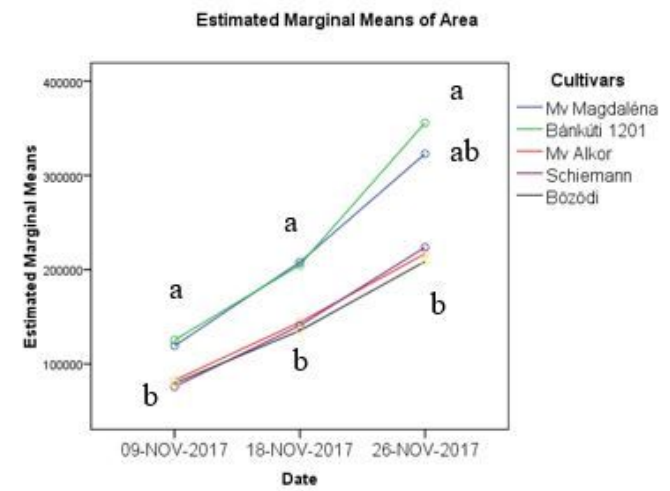

b

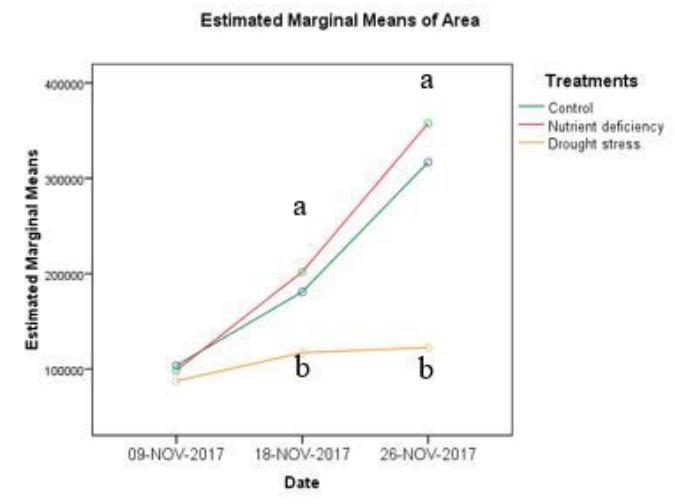

c

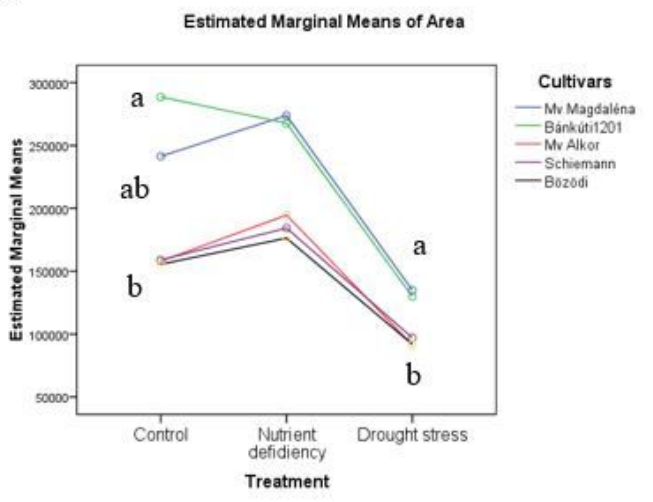

Figure 2

The impact of a) cultivar*date, b) treatment*date, and c) cultivar*treatment on the area of plot-grown wheat cultivars assessed by VIS-based digital image analysis. Within date or within treatment significant differences at $p<0.05$ based on Tukey post hoc test are marked with different letters. 


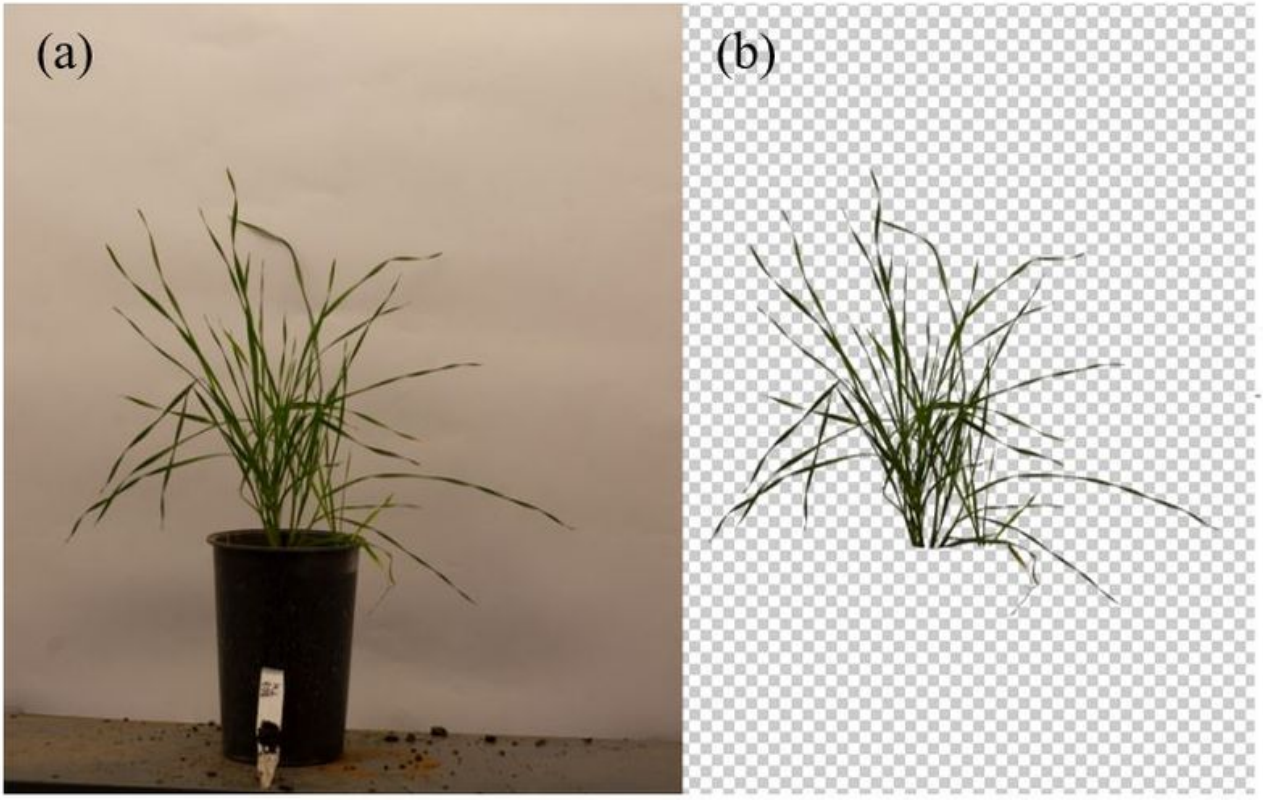

(c)

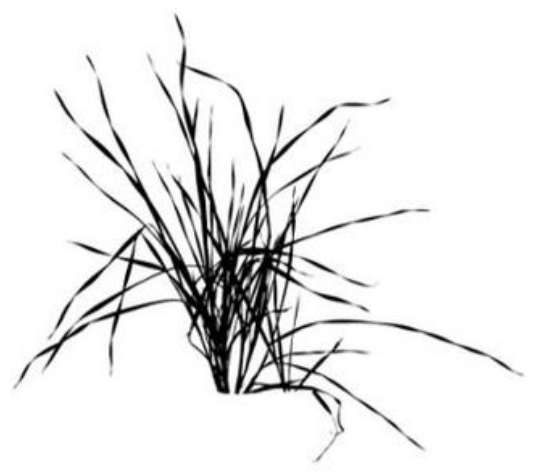

Figure 3

The process of segmenting digital images with Adobe Photoshop CC 20.0.4: a) original RAW image, b) separated plant material, c) 16-bit TIFF image.
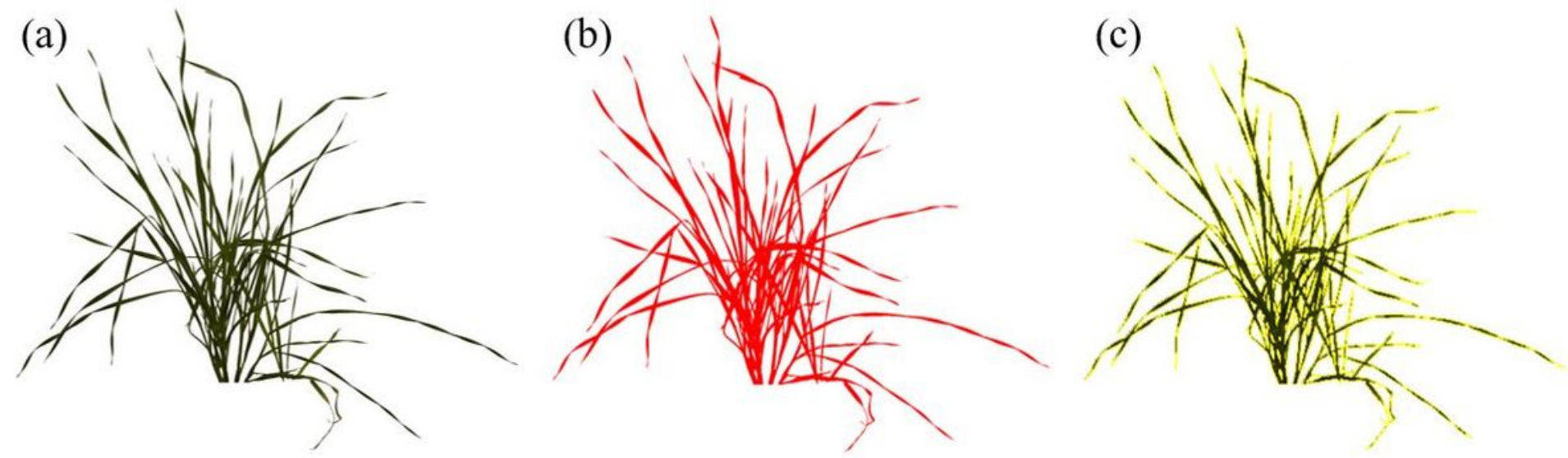

Figure 4

The process of measuring the projected area using the ImageJ software: a) RGB stack, b) tresholded image in HSB color space, c) filtered object.

\section{Supplementary Files}

This is a list of supplementary files associated with this preprint. Click to download.

- Appendix.docx 